\title{
Design of deep pile caps by strut-and-tie models
}

\section{Dimensionamento de blocos rígidos sobre estacas com auxílio de modelos de bielas e tirantes}

\author{
D. M. SANTOS a,b \\ danielmiranda@usp.br \\ https://orcid.org/0000-0002-9927-8138 \\ M. L. CARVALHO a,c \\ mth.carvalho@hotmail.com \\ https://orcid.org/0000-0002-4710-1250 \\ F. R. STUCCHI a,b \\ fernando.stucchi@usp.br \\ https://orcid.org/0000-0003-4149-0985
}

\begin{abstract}
There are many methods for designing pile caps, but there is still no consensus on which one provides the best approach for the practical engineers. In Brazil, many structural designers use the classical Blévot method; however, the applicability of the method has been questioned after the revision of the NBR 6118 standard for design of concrete structures in 2014. To support structural designers, a strut-and-tie model has recently been developed that relates the classical method to the most current concepts of strut-and-tie models. The theoretical bearing capacity of four-pile cap obtained through several strut-and-tie models are compared with experimental tests. The results show that this recently developed model is suitable for the design of deep pile cap.
\end{abstract}

Keywords: pile caps, strut-and-tie models, design, reinforced concrete.

\section{Resumo}

Existem muitos métodos de dimensionamento de blocos de fundações, mas ainda não há consenso sobre qual método fornece a melhor abordagem para o engenheiro de projetos. No Brasil, muitos projetistas de estruturas utilizam o método clássico de Blévot, no entanto, com a revisão da norma NBR 6118 de projeto de estruturas de concreto em 2014, o meio técnico tem sido confrontado com dúvidas quanto a aplicabilidade desse método pela regulamentação vigente. De forma a contribuir com o tema, recentemente foi desenvolvido um modelo de bielas e tirantes que relaciona o método clássico com os conceitos mais atuais de modelos de bielas e tirantes. As resistências teóricas de blocos sobre 4 estacas obtidas através de vários modelos de bielas e tirantes são comparadas com ensaios experimentais. Os resultados obtidos mostram que o modelo recentemente desenvolvido é adequado para o dimensionamento de blocos rígidos.

Palavras-chave: blocos de fundação, modelos de bielas e tirantes, dimensionamento, concreto armado. 


\section{Introduction}

Pile caps are tridimensional structural elements whose function is to transfer the forces in the column to a set of piles. These elements generally have low flexural reinforcement ratio and with no shear reinforcement within them. The lack of stirrups makes the structural behavior of the pile caps complex and highly dependent on the tensile strength of the concrete and on the confinement of plain concrete. Currently, national and international standards or codes (e.g. [4] and [19]) permit two different provisions for designing pile caps: one based on sectional analysis and the other on strut-and-tie models (STM). The first is the same sectional approach used for two-way slabs, while the second is based on the complete flow of forces within the pile caps using strut-and-tie models.

The approach by strut-and-tie models is generally recognized as the most appropriate for pile-caps design. Figure 1 shows a strutand-tie model for four-pile caps.

The revision of NBR 6118 [4] in 2014 added specific rules for the design of concrete structures by strut-and-tie models. However, the design strength of concrete struts and the design values of the compressive stress within nodes by this standard (established for the design of plane elements) are lower than those prescribed in the most widely used method in Brazil, known as Blévot or classical method (Blévot and Frémy [1]), raising some doubts and difficulties in the technical community because of the conservatism in using such method with the resistance limits of NBR 6118 [4]. For the reason mentioned above, it increased the interest of structural engineers in the Fusco Method [5], which maintains, with small changes, the well-established practice by the classical method. Although the Fusco Method [5] can be considered a consistent adaptation of the Blévot method and allows using the prescriptions of NBR 6118 [4] without exaggerating in conservatism, it does not

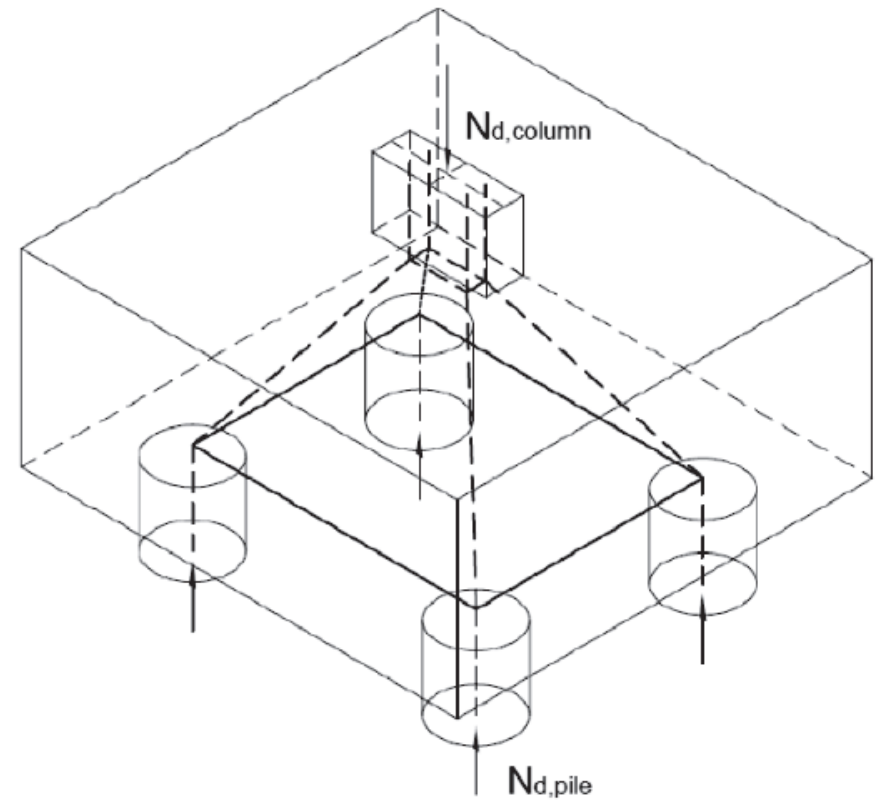

Figure 1

Three-dimensional truss model for four-pile cap follow the modern concepts of strut-and-tie models (Schlaich et al. [20] and stress fields (Muttoni et al. [21]).

In order to align the normative prescriptions with the design methods of pile caps, a new method was developed and presented by Santos et al. [3]. This method is based on a strut-and-tie model that mixes the classical and the Fusco methods in a consistent way following the modern concepts of strut-and-tie models and stress fields.

In this paper, some design methods of pile caps by strut and tie models are reviewed. The newly developed model by Santos et al., [3] is discussed and results from tests are reviewed and compared with predictions from the different design methods. This comparative study also indicates the suitability of the recently developed model, and possible improvements are outlined.
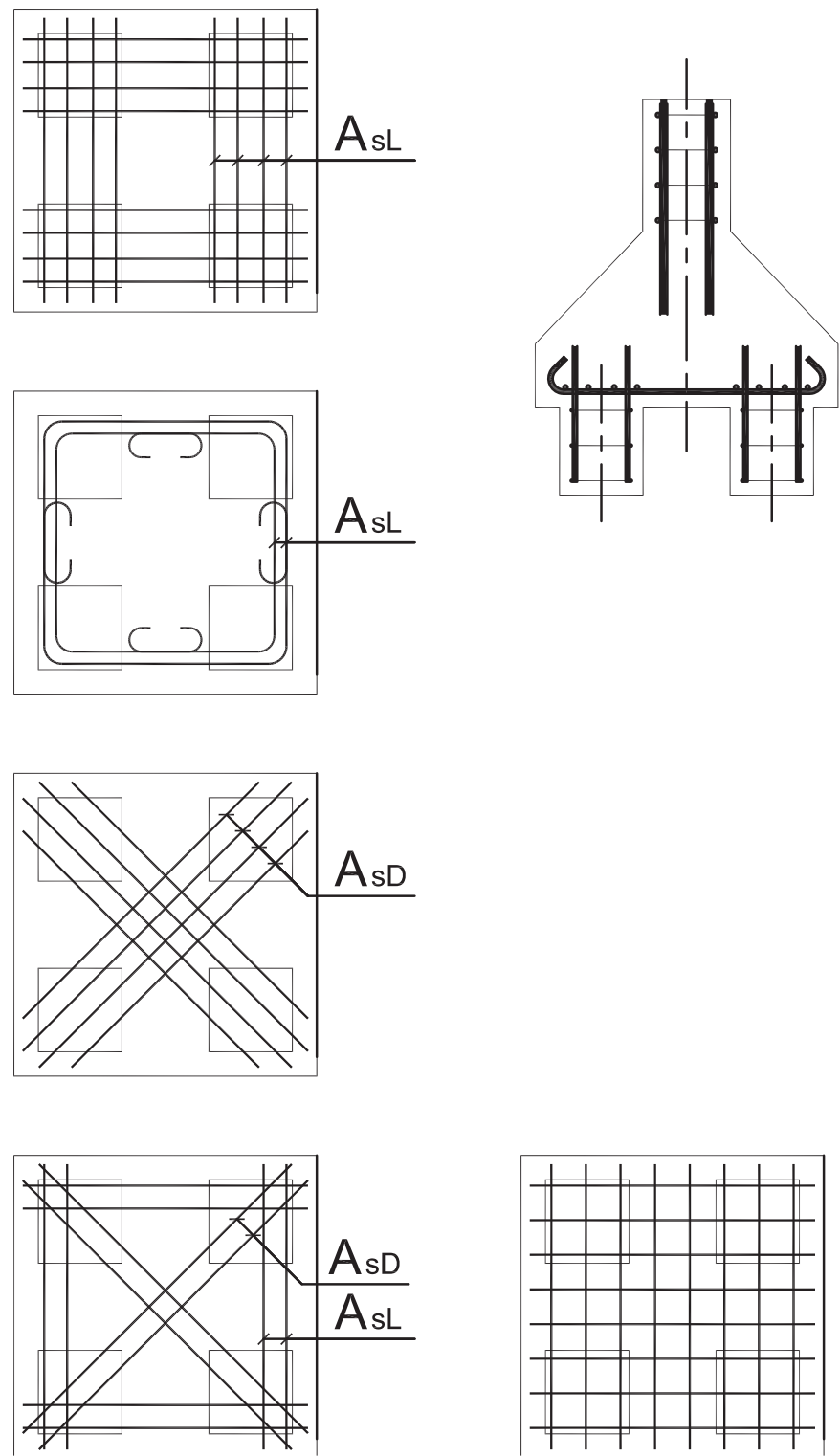

Figure 2

Reinforcement layouts tested by Blévot e Frémy [1] for four-pile caps (adapted from [1]) 


\section{Experimental data}

There are several experimental test data on the bearing capacity of pile caps in the technical literature. A brief summary of these test results is presented.

The tests most known in Brazil were carried out by Blévot and Frémy [1] who tested 116 pile caps with various features. There were 59 four-pile caps, 45 three-pile caps and 12 two-pile caps. Additionally, 94 tests at reduced-scale and 22 tests at full-scale. From the tests results and the strut-and-tie model proposed by M. Lebelle for designing footings, these researchers proposed a simplified strut-and-tie model for designing pile caps. This model is well established in Brazil and widely used by structural design offices.

Figure 2 shows the different reinforcement arrangements used in four-pile caps tests. Blévot and Frémy [1] noted that the four-pile caps with grid reinforcement arrangement had less bearing capacity than a similar pile cap with bunched square layout (in the case of four-pile caps, they observed $20 \%$ less bearing capacity). This finding, reproduced by other researchers (Clarke [9], Suzuki et al. [10]), shows the effectiveness of the strut-and-tie models over the sectional method (CEB-FIP Bulletin 73 [2]), because the STM indicates that the tension forces are concentrated over the piles.

Clarke [9] tested 15 four-pile caps. The arrangement of the reinforcements and the anchorage of the bars were the main parameters studied. He also observed that the bearing capacity of pile caps is smaller with grid reinforcement patterns.

The experimental campaign of Blévot and Frémy [1] and Clarke and [9] did not use strain gauges in reinforcement or in the concrete. On the one hand, there is uncertainty about the existence of other factors that negatively influence the bearing capacity of the pile caps, such as insufficient bar anchorage. On the other hand, these tests are extremely important, since there are few pile caps test data with instrumented bunched square layouts.

Adebar, Kuchma and Collins [6] tested 5 four-pile caps. The specimens had piles with different distances from the column, which increased the uncertainties in the distribution of the pile forces and, consequently, in the design of the reinforcements. To solve the issue, the researchers assumed that the column load would be equally shared among all the piles. However, this hypothesis was not observed by the measurements made throughout the test. Nevertheless, the experimental campaign was instrumented, and some of the results are valuable for studying the behavior of pile caps.

Adebar, Kuchma and Collins [6] measured the longitudinal strains on the top surfaces across the widths of the pile caps. The objective was to investigate the assumption of the sectional method that the full width of the pile cap uniformly resists the applied bending moment, i.e., the compression on the top surfaces would be uniform. The measured strains showed that, even though the flexural reinforcement was yielding and the pile cap was very close to failure, the compressive strains on the top surface remained relatively low ([6]). Moreover, the distribution of the strains was very different from the hypothesis of uniformity, indicating that the compressive stresses due to the bending moment were resisted mainly by the central portion of the pile cap, i.e., by the compressed node below the column, as suggested by strut-and-tie models.

Suzuki, Otsuki and Tsubana ([10] and [11]), Suzuki, Otsuki and Tsuchiya ([12]) and Suzuki and Otsuki ([13]) tested 94 four-pile caps. Most of these tests had a grid arrangement of the reinforcement, although bunched square layouts were observed to lead to higher strengths. Cao [14] tested 18 four-pile caps with rectangular columns; one side had the same size as the width of pile cap. The tests used the grid reinforcement pattern.

\section{Table 1}

Selected tests performed by Blévot e Frémy [1]

\begin{tabular}{|c|c|c|c|c|c|c|c|c|c|c|}
\hline Nome & $\begin{array}{c}\mathrm{L}^{1} \\
(\mathrm{~cm})\end{array}$ & $\begin{array}{c}d^{2} \\
(\mathrm{~cm})\end{array}$ & $\begin{array}{c}a_{c}^{3} \\
(\mathrm{~cm})\end{array}$ & $\begin{array}{l}a_{\text {pile }}{ }^{4} \\
(\mathrm{~cm})\end{array}$ & $\begin{array}{c}A_{\mathrm{sL}}{ }^{5} \\
\left(\mathrm{~cm}^{2}\right)\end{array}$ & $\begin{array}{c}\mathrm{A}_{\mathrm{sD}}{ }^{6} \\
\left(\mathrm{~cm}^{2}\right)\end{array}$ & $\begin{array}{c}f_{y^{7}} \\
\left(M^{\prime} P a\right)\end{array}$ & $\begin{array}{c}f^{{ }^{8}} \\
(\mathrm{MPa}) \\
\end{array}$ & $\begin{array}{c}f^{{ }^{9}} \\
(\mathrm{MPa})\end{array}$ & $\begin{array}{c}\mathbf{F}_{\text {test }}{ }^{10} \\
\text { (ft) }\end{array}$ \\
\hline $4 \mathrm{~N} 2$ & 120 & 64.95 & 50 & 35 & 24.13 & 19.63 & 278.5 & 300.3 & 37.10 & 658.00 \\
\hline $4 \mathrm{~N} 2^{\text {bis }}$ & 120 & 66.36 & 50 & 35 & 15.00 & 12.84 & 498.8 & 474.5 & 34.15 & 739.00 \\
\hline $4 \mathrm{~N} 4$ & 120 & 91.07 & 50 & 35 & 19.63 & 19.63 & 291.4 & 291.4 & 35.35 & 753.00 \\
\hline $4 \mathrm{~N} 4^{\mathrm{bis}}$ & 120 & 91.95 & 50 & 35 & 12.84 & 12.84 & 486.4 & 486.4 & 42.30 & 875.00 \\
\hline 2,2 & 42 & 27.65 & 15 & 14 & - & 4.52 & - & 355.0 & 32.82 & 81.00 \\
\hline 2,3 & 42 & 26.94 & 15 & 14 & 1.57 & 2.25 & 290.5 & 333.5 & 31.60 & 74.00 \\
\hline 3,1 & 42 & 18.08 & 15 & 14 & 2.01 & - & 469.0 & - & 32.10 & 47.50 \\
\hline $1 \mathrm{~A}, 2^{\mathrm{bis}}$ & 42 & 27.00 & 15 & 14 & - & 5.48 & - & 492.3 & 33.25 & 117.75 \\
\hline $1 \mathrm{~A}, 3$ & 42 & 27.00 & 15 & 14 & 1.83 & 1.83 & 523.0 & 523.0 & 36.60 & 118.50 \\
\hline $9, A 1$ & 42 & 47.39 & 15 & 14 & 4.52 & - & 459.0 & - & 27.27 & 120.00 \\
\hline $9, \mathrm{~A} 2$ & 42 & 47.08 & 15 & 14 & 8.04 & - & 467.0 & - & 40.81 & 190.00 \\
\hline $10,1 a$ & 42 & 22.62 & 15 & 14 & 4.52 & - & 446.0 & - & 34.60 & 85.00 \\
\hline $10,1 b$ & 42 & 22.11 & 15 & 14 & 2.26 & 3.08 & 456.0 & 480.0 & 43.11 & 80.00 \\
\hline $11,1 a$ & 42 & 27.16 & 15 & 14 & 4.52 & - & 311.0 & - & 26.88 & 56.25 \\
\hline $11,1 \mathrm{~b}$ & 42 & 27.16 & 15 & 14 & 4.52 & - & 311.0 & - & 19.48 & 49.25 \\
\hline $11,2 a$ & 42 & 28.48 & 15 & 14 & 3.14 & - & 444.7 & - & 30.86 & 55.75 \\
\hline $11,2 \mathrm{~b}$ & 42 & 27.46 & 15 & 14 & 3.14 & - & 440.7 & - & 30.00 & 58.50 \\
\hline
\end{tabular}

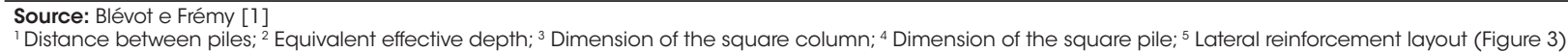

${ }^{6}$ Diagonal reinforcement layout (Figure 3 ); ${ }^{7}$ Yield strength of lateral reinforcement; ${ }^{8}$ Yield strength of diagonal reinforcement; ${ }^{9}$ Compressive strength of concrete;

${ }_{10}$ Failure load. 
Table 2

Selected tests performed by Clarke [9] and Susuki et al. [10]

\begin{tabular}{|c|c|c|c|c|c|c|c|c|}
\hline Nome & $\begin{array}{c}\mathrm{L}^{1} \\
(\mathrm{~cm})\end{array}$ & $\begin{array}{c}d^{2} \\
(\mathrm{~cm})\end{array}$ & $\begin{array}{c}a_{p}^{3} \\
(c m)\end{array}$ & $\begin{array}{c}\phi_{\text {est }}^{4} \\
(\mathrm{~cm})\end{array}$ & $\begin{array}{c}A_{\mathrm{sL}{ }^{2}} \\
\left(\mathrm{~cm}^{2}\right)\end{array}$ & $\begin{array}{c}f_{\mathrm{yL}^{7}} \\
(\mathrm{MPa})\end{array}$ & $\begin{array}{c}f^{c 9} \\
(\mathrm{MPa})\end{array}$ & $\begin{array}{c}F_{\text {ensaio }^{10}} \\
\text { (ff) }\end{array}$ \\
\hline \multicolumn{9}{|c|}{ Clarke [9] } \\
\hline A2 & 60 & 40 & 20 & 20 & 5.00 & 410 & 27.2 & 142 \\
\hline A3 & 60 & 40 & 20 & 20 & 4.95 & 410 & 30.4 & 134 \\
\hline A5 & 60 & 40 & 20 & 20 & 5.00 & 410 & 26.6 & 140 \\
\hline A6 & 60 & 40 & 20 & 20 & 4.95 & 410 & 25.8 & 123 \\
\hline A8 & 60 & 40 & 20 & 20 & 5.00 & 410 & 27.2 & 151 \\
\hline Nome & $\begin{array}{c}\mathrm{L}^{1} \\
(\mathrm{~cm})\end{array}$ & $\begin{array}{c}d^{2} \\
(\mathrm{~cm})\end{array}$ & $\begin{array}{c}a_{p^{3}} \\
(\mathrm{~cm})\end{array}$ & $\begin{array}{c}\phi_{\text {est }}^{4} \\
(\mathrm{~cm})\end{array}$ & $\begin{array}{c}\mathrm{A}_{\mathrm{sL}^{5}} \\
\left(\mathrm{~cm}^{2}\right)\end{array}$ & $\begin{array}{c}f_{\mathrm{yl}}{ }^{7} \\
(\mathrm{MPa})\end{array}$ & $\begin{array}{c}\mathrm{f}^{\circ 9} \\
(\mathrm{MPa})\end{array}$ & $\begin{array}{c}\mathrm{F}_{\text {ensaio }}{ }^{10} \\
\text { (tf) }\end{array}$ \\
\hline \multicolumn{9}{|c|}{ Susuki et al. [10] } \\
\hline BPC-20-1 & 54 & 15 & 30 & 15 & 2.85 & 413 & 21.9 & 51.9 \\
\hline BPC-20-2 & 54 & 15 & 30 & 15 & 2.85 & 413 & 19.9 & 52.9 \\
\hline BPC-25-1 & 54 & 20 & 30 & 15 & 3.57 & 413 & 18.9 & 81.8 \\
\hline BPC-25-2 & 54 & 20 & 30 & 15 & 3.57 & 413 & 22.0 & 81.3 \\
\hline BPC-20-30-1 & 50 & 15 & 30 & 15 & 2.14 & 405 & 29.8 & 50.0 \\
\hline BPC-20-30-2 & 50 & 15 & 30 & 15 & 2.14 & 405 & 29.8 & 49.5 \\
\hline BPC-30-30-1 & 50 & 25 & 30 & 15 & 2.85 & 405 & 28.9 & 103.9 \\
\hline BPC-30-30-2 & 50 & 25 & 30 & 15 & 2.85 & 405 & 30.9 & 102.9 \\
\hline BP-30-25-1 & 50 & 25 & 25 & 15 & 2.85 & 405 & 29.1 & 85.3 \\
\hline BPC-30-25-2 & 50 & 25 & 25 & 15 & 2.85 & 405 & 29.2 & 87.2 \\
\hline
\end{tabular}

Source: Clarke [9] e Susuki et al. [10]

${ }^{1}$ Distance between piles; ${ }^{2}$ Effective depth; ${ }^{3}$ Dimension of the square column; ${ }^{4}$ Diameter of the pile; ${ }^{5}$ Lateral reinforcement layout (Figure 3 ); ${ }^{6}$ Yield strength of lateral reinforcement; ${ }^{7}$ Compressive strength of concrete; ${ }^{8}$ Failure load.

Several tests of two and three-pile caps were performed at the São Carlos School of Engineering of the University of São Paulo under the supervision of Prof. José Samuel Giongo (Munhoz [17], Barros [16], Miguel [15], among others).

Tables 1 and 2 show the main details of the selected tests. The experimental data was compared with the theoretical value obtained through the strut-and-tie models discussed below. Square four-pile caps with bunched reinforcement layout were chosen for this analysis. Additionally, the adopted minimum slope of diagonal strut, according to the Blévot method, was $33^{\circ}$. Comparisons with four-pile caps using grid arrangements are discussed in Carvalho [22].

\section{Strut-and-tie models applied to pile caps}

\subsection{Blévot \& Frémy [1]}

Blévot \& Frémy [1] present a simplified strut-and tie model according to Figure 3.

In this model, the vertical projection of the strut is the effective depth (d) and the horizontal projection $\left(\mathrm{L}_{\text {proj }}\right)$ is the distance from the center of the load portion in the column to the axis of the pile, i.e., $\left(\frac{L}{2}-\frac{a_{c}}{4}\right) \sqrt{2}$ for four-pile caps. The tension force in the plane of the reinforcement is determined by:

$F_{t d}=N_{d, p i l e} \cdot \operatorname{cotg} \theta$

In which:

$\operatorname{cotg} \theta=\frac{L_{\text {proj }}}{d}$

In the case of two-pile caps, $F_{t d}$ is the force in the reinforcement.
However, from the results from the tests, Blévot and Frémy [1] proposed an additional factor of 1.15 in order to avoid lower safety coefficients than those specified at the time. In the case of three-pile caps (or more piles), this factor does not exist, yet it is necessary to decompose $\mathrm{F}_{\mathrm{td}}$ in the direction of the reinforcement.

Furthermore, to prevent the diagonal strut of concrete from crushing, [1] establishes the limits below:

$\frac{N}{n \cdot A_{p} \cdot \sin ^{2}(\theta)} \leq \alpha_{B} \cdot \sigma_{28}$

$\frac{N}{A_{c} \cdot \sin ^{2}(\theta)} \leq \alpha_{B} \cdot \sigma_{28}$

in which,

$A_{p}$ - area of piles;

$A_{c}$ - area of column;

$\theta-$ angle between axis of diagonal strut and the tension chord in the plane of reinforcement $\left(\theta=\operatorname{arctg} \frac{d}{L_{\text {proj }}}\right)$;

$\alpha_{B}$ - factor of 0.6 for two-pile caps, 0.75 for three-pile caps e 0.9 for pila caps with 3 or more piles;

$\sigma_{28}$ - cylinder compressive strength of concrete at 28 days $(h=2 \varnothing)$. Equations (3) and (4) were adapted to the limit states safety format, resulting (in Brazilian practice) in the expressions below:

$\sigma_{c d, p}=\frac{N_{d, p}}{A_{p} \cdot \sin ^{2}(\theta)} \leq \alpha \cdot f_{c d}$

$\sigma_{c d, c}=\frac{N_{d, c}}{A_{c} \cdot \sin ^{2}(\theta)} \leq \alpha \cdot f_{c d}$ 

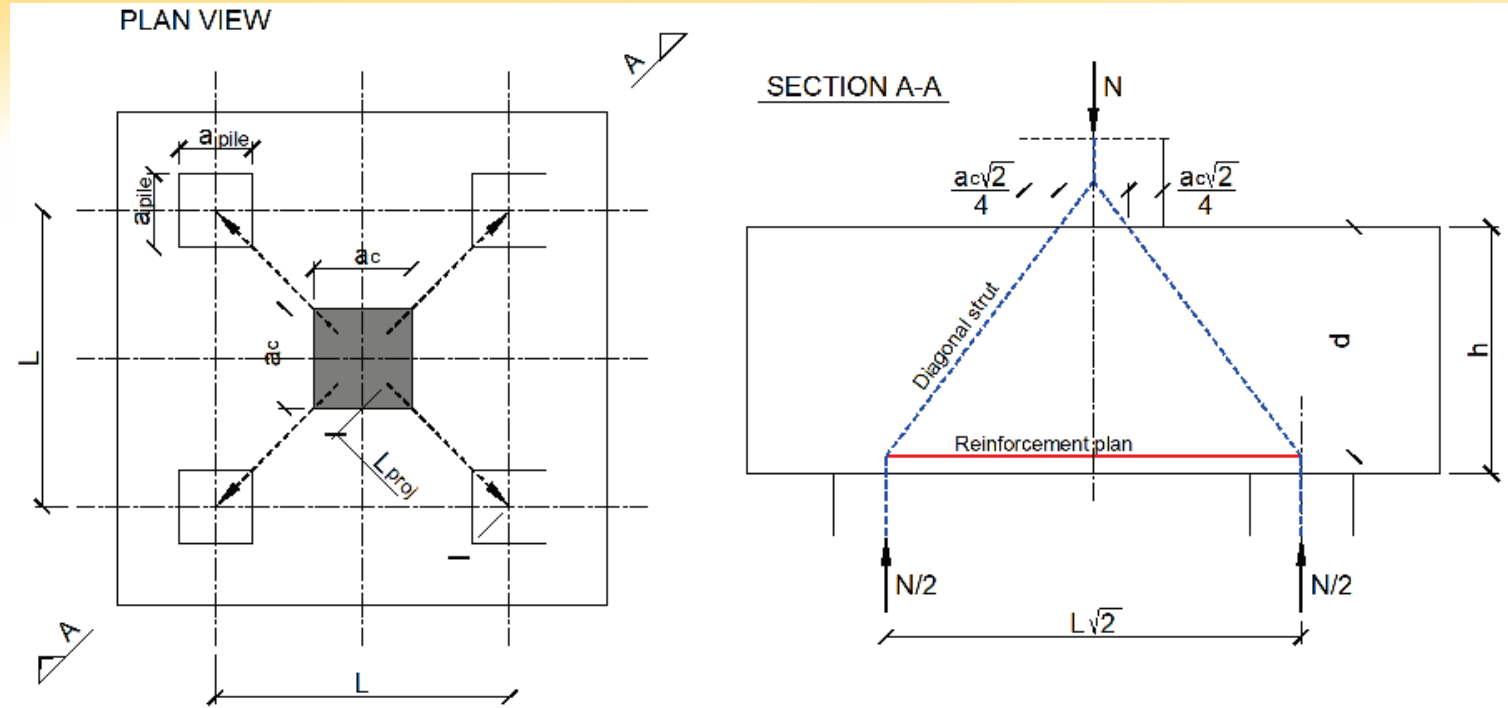

\section{Figure 3}

Classical strut-and-tie model for four-pile caps (BLEVOT e FRÉMY [1])

In which,

$\sigma_{c d, p}-$ compressive design stress in concrete struts at the top of the piles;

бcd,c - compressive design stress in concrete struts at the base of the column;

$\mathrm{N}_{\text {d.est }}$ - design value of pile reaction;

$\mathrm{N}_{\mathrm{d} \text {, pilar }}$ - design value of column load;

$\alpha$ - factor equal to 1.4 for two-pile cap, 1.75 for three-pile cap and

2.1 for four-pile cap

$\mathrm{f}_{\mathrm{cd}}$ - design value of concrete compressive strength.

According to [1], the applicability of the simplified strut-and-tie model is:

$40^{\circ}<\theta<55^{\circ}$

The recommendation is $\theta \geq 45^{\circ}$.

\subsection{Fusco [5]}

The design method proposed by Fusco [5], in 1995, is based on strut-andtie models, in principle, very similar to the Blévot and Frémy [1] method. This method differs from the classical method in a fundamental point: the geometry of the nodes and, consequently, in the verification of safety against crushing of the concrete strut. Moreover, [5] argues that the direct strut can be formed if the minimum inclination angle of the diagonal strut $(\theta)$ is $26.6^{\circ}(\operatorname{arctg} 1 / 2)$, but, for safety reasons, recommends the minimum angles of $33.7^{\circ}(\operatorname{arctg} 2 / 3)$.

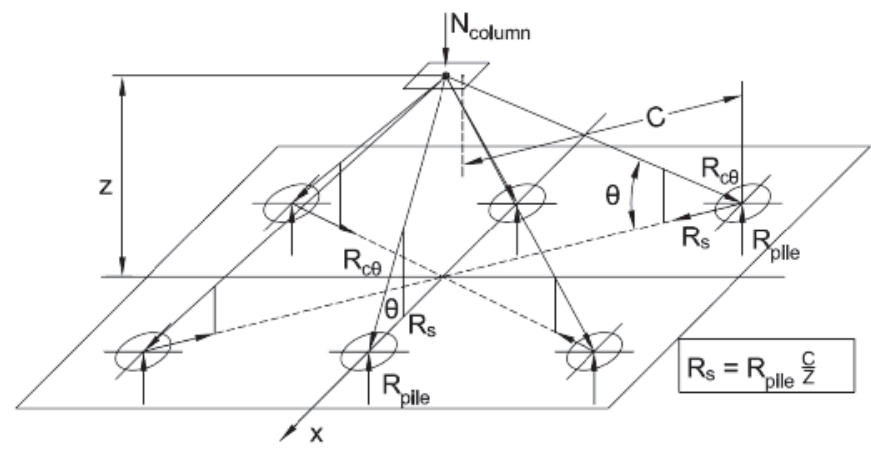

Figure 4

Basic behavior of pile caps (FUSCO [5])
The geometry of the node at the base of the column assumes a $63.4^{\circ}$ spreading load (see Figure 5). Additionally, for the design of the pile cap, [5] considers that the column load is the design compression resistance of the column. In addition, [5] defines a depth $x$ of the top node in which the vertical stress in the spreading area is equal to:

$\sigma_{c 2 d, c}=\frac{N_{d, c}}{A_{c, s p}}=\frac{N_{r d}}{(a+4 x)(b+4 x)}=0,2 f_{c d}$

The horizontal plane in which the vertical stress equals $20 \%$ of the design value of concrete compressive strength is justified, since [5] limited the compressive stresses in the concrete struts in fcd and imposed the minimum inclination angle of the diagonal strut (i.e. $\theta=26.6^{\circ}$ ). Thus, the verification of safety against crushing concrete strut is ensured by checking if the inclination angles of the diagonal struts is higher than the recommend value of $33.7^{\circ}$ (arctan 2/3). Following the determination of this plan, the Fusco

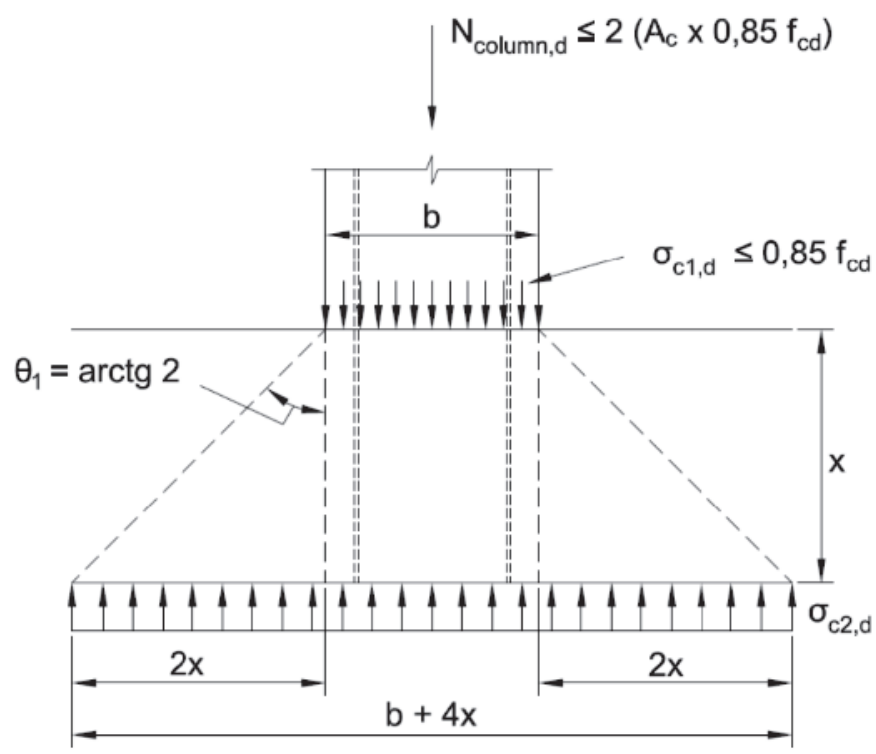

Figure 5

Stresses in the horizontal plan of the pile cap (FUSCO [5]) 
method can be assumed equivalent to the Blévot method with fictional enlarged column $\left(A_{c, s p}\right)$ and smaller effective depth $(d-x)$, then:

$\sigma_{c d, c}=\frac{N_{d, c}}{A_{c, s p} \cdot \sin ^{2}(\operatorname{arctg} 1 / 2)}=\frac{0,20 f_{c d}}{\sin ^{2}(\operatorname{arctg} 1 / 2)}=f_{c d}$

Where,

$A_{c, s p}=\left(a_{c}+4 x\right)\left(b_{c}+4 x\right)$

The crushing strength of concrete strut equals $\mathrm{f}_{\mathrm{cd}}$; according to [5], it is conservative because of the confinement in a partially loaded area. Fusco [5] considers that the reinforcement contributes to the design compression resistance of the column; it is thus necessary to transfer the forces between steel bar and concrete within the pile cap. According to [5], short bond lengths of 10 to 15 diameters of the bars are perfectly feasible.

In order to simplify the determination of the depth in which the verln order to simplify the determination of the depth in which the vertical tension is equal to $0.2 f_{c d}$, [5] determined values of $x$ depending on the longitudinal reinforcement ratio in the column (Figure 6).

At the top of the piles (Figure 7), the stresses in the concrete struts depend of the spreading area of the pile until the plane of the reinforcement, where the equilibrium between concrete strut, pile reaction and reinforcement is obtained.

The method assumes that the distance between the reinforcement and the base of the pile cap is approximately:

$d^{\prime} \cong 0.20 a_{\text {pile }}$

Thus, the spreading diameter (or side) of the pile is:

$a_{p, s p}=a_{\text {pile }}+2 d^{\prime} \approx 1.4 a_{\text {pile }}$



\section{Figure 6}

Strength of the diagonal strut below the column (FUSCO [5])
Since the crushing strength of the diagonal strut is assumed to be $f_{c d}$, it is possible, in a similar way to that of the node at the base of the column, to indirectly limit the stress in the concrete strut by:

$\sigma_{c 2 d, p i l e}=\frac{N_{d, p}}{n_{\text {pile }} \cdot A_{p, s p}} \leq 0.20 f_{c d}$

Where $n_{\text {pile }}$ is the number of piles in the pile cap and $A_{p, s p}$ is the spreading area of the pile.

Although the node at the base of the column assumes a $63.4^{\circ}$ spreading load, at the top of the piles, Fusco [5] recommends a $45^{\circ}$ spreading of the pile reaction.

The Fusco method can be considered an adaptation of the Blévot method by replacing the actual areas of the column and piles for the correspondent spreading areas. The use of the spreading areas results in lower stresses in the concrete struts when compared to the Blévot method and allows using the design strength of concrete struts and the design values of stresses within the nodes, which is permitted in the codes and standards. Nevertheless, it is important to note that these limits do not generally consider confinement (they are valid for plane elements).

\subsection{Adebar e Zhou (1996)}

Adebar and Zhou ([7] and [8]) proposed a design method based on analytical and experimental studies of bearing strength of compressive struts confined by plain concrete. They suggested that when designing deep pile cap without sufficient reinforcement to ensure redistribution of internal forces after cracking, the maximum bearing stress should be limited to

$f_{\text {bie }}=f^{\prime}{ }_{c}+6 \alpha \beta \sqrt{f^{\prime}}$

Where

$f^{\prime}$ - - specified compressive strength of concrete (according to ACl 318 [19]);

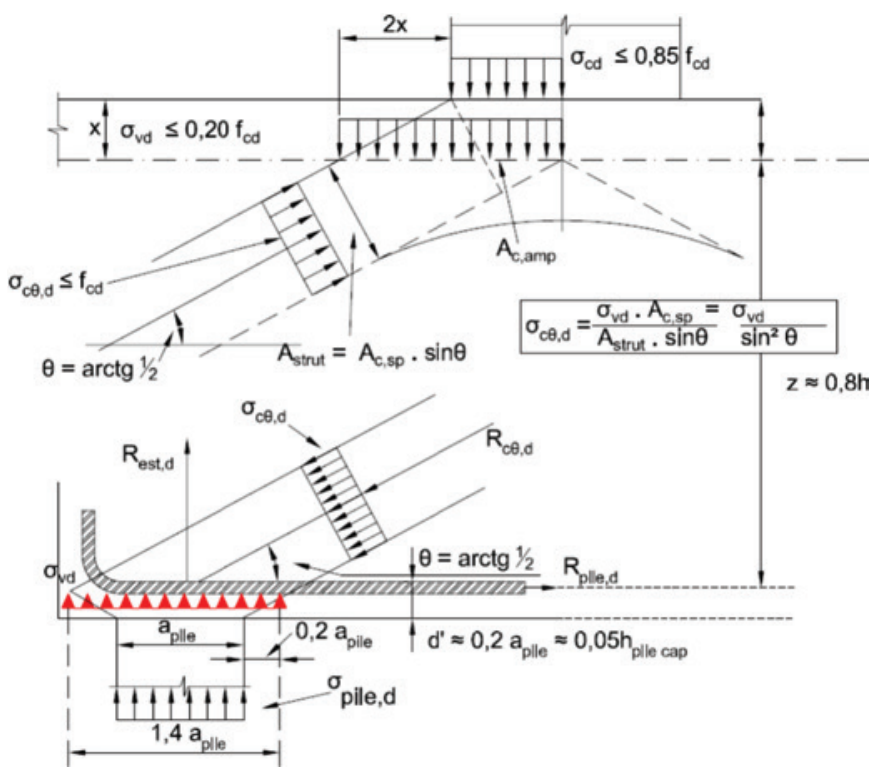

Figure 7

Strength of the diagonal strut above the piles (Fusco [5]) 
$\alpha=\frac{1}{3} \cdot\left(\sqrt{A_{2} / A_{1}}-1\right) \leq 1,0$

$\beta=\frac{1}{3} \cdot\left(\frac{h_{s}}{b_{s}}-1\right) \leq 1,0$

Parameter $\alpha$ accounts for the confinement of the compression strut. The ratio $A_{2} / A_{1}$ is similar to the ratio $A_{c 1} / A_{c 0}$ of NBR 6118 [4] for local crushing in partially loaded area. Parameter $\beta$ accounts for the geometry of the compression strut. To calculate the bearing strength of the nodal zone at the base of the column, where two or more compression struts meet, the ratio $h_{s} / b_{s}$ can be approximated as ([8]).

$\frac{h_{s}}{b_{s}} \approx \frac{2 d}{a_{c}}$

Where $a_{c}$ is the dimension of a square column.

To calculate the bearing strength of the nodal zone above a pile, where only one compression strut is anchored, the ratio $h_{s} / b_{s}$ can be approximated as ([8]).

$\frac{h_{s}}{b_{s}} \approx \frac{d}{a_{\text {pile }}}$

where $a_{\text {pile }}$ is the diameter of a round pile or the dimension of a square pile.

The proposed strut-and-tie model approach is intended for designing deep pile caps, rather than slender pile caps ([8]). The researchers recognize that it is difficult to separate the two types and some pile caps may be somewhere in between.

The methodology proposed in [7] and [8] is not clear about which lever arm should be used for determining the reinforcement; hence, this method was not compared with the test results (Tables 1 and 2).

\subsection{Santos et al. [3]}

The recently developed model by Santos et al. [3] combined the simplified equations of bearing stresses of the Blévot model with the concept of spreading the load of the Fusco model.

This model was developed from the need to use the prescriptions of the Brazilian standard. The design strength of concrete struts and the design values of the compressive stress within nodes in NBR6118 [4] are based on tests in plane elements. However, the proposed model is more general and not limited to specific values. The model adapts the classical method with the more consistent consideration of the geometry of the node below the column. In addition, a small adjustment was proposed in the stress verification within the nodes above the piles, based on the recommendation of Fusco [5], as shown in Figure 8.

The bearing stress can be estimated by adapting equations (5) and (6). In this method, the area of the piles and column are replaced by the 45 spreading area, which allows a more rational way of determining the compressive strut area in the node regions. The ideal angle for spreading the load is the same as the angle of inclination of the diagonal struts; however, in more complex geometries, in which the struts do not have the same angle of inclination, the 45 spreading load seems to simplify the model without significant losses of precision.

A comparison between the geometries of the Blévot model and the strut-and-tie models (STM) proposed by Schlaich et al. [20] is depicted in Figure 9, which shows that the models define inclinations of diagonal struts in different ways. While the "Blévot method" defines the tangent of the angle by the ratio $d / L_{\text {proj }}$, the STM defines by $z / L_{\text {proj }}$, where, $z=d-0.5 y$ and $y$ is the depth of the neutral axis or the depth of the node below the column.

To prevent crushing of the diagonal strut of concrete, [3] establishes the limits below:

$\sigma_{c d, p}=\frac{N_{d, p}}{A_{p, s p} \cdot \sin ^{2}(\theta)} \leq f_{c d 3}$
$\sigma_{c d, c}=\frac{N_{d, c}}{A_{c, s p} \cdot \sin ^{2}(\theta)} \leq f_{c d 1}$
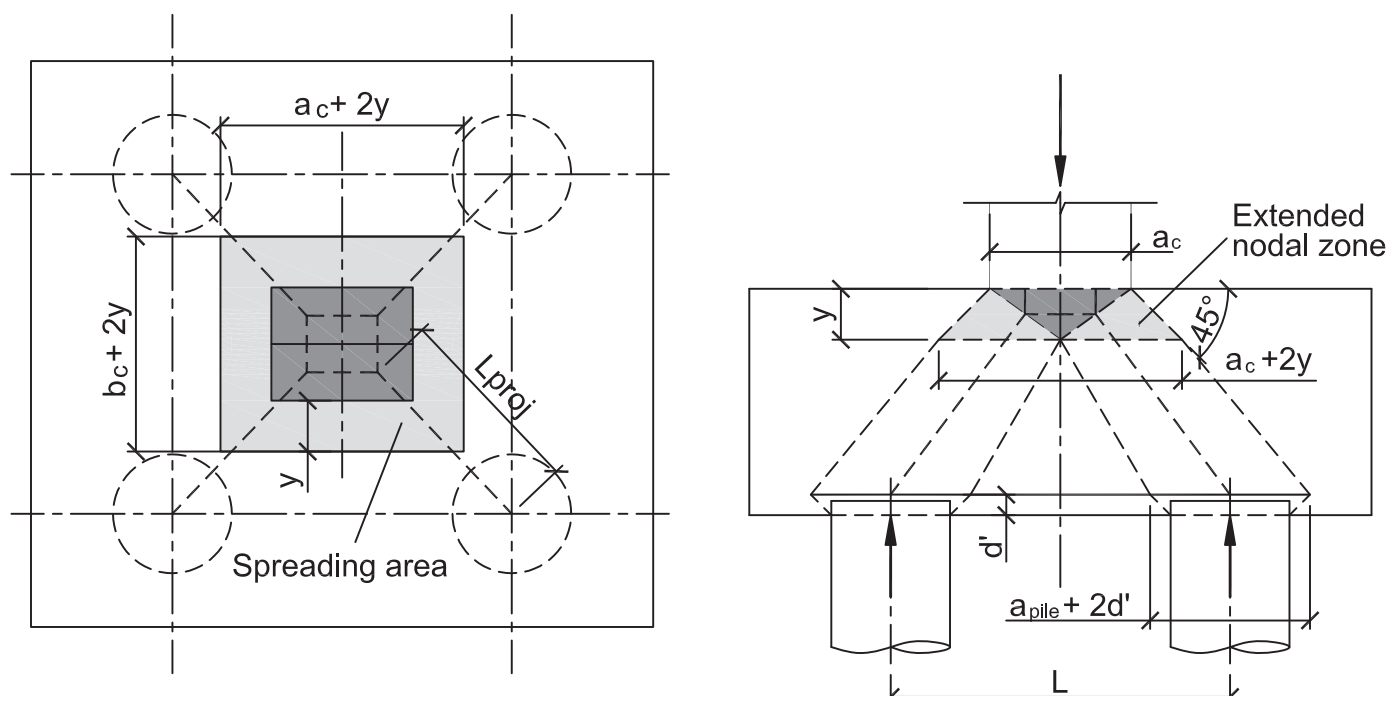

Figure 8

Strut-and-tie model with the compressive node inside the pile cap (SANTOS et al. [3]) 


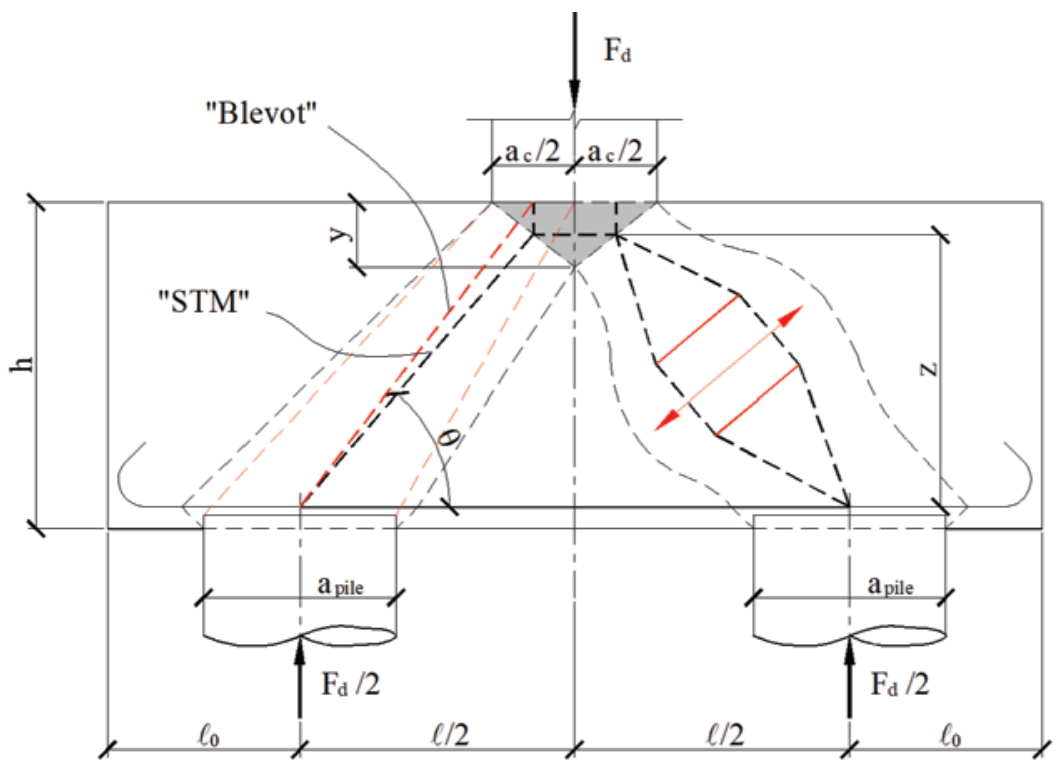

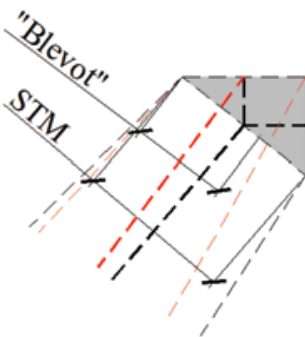

Geometry

\section{Figure 9}

\section{Comparisons between strut-and-tie models and Blévot e Frémy [1] model (SANTOS et al. [3])}

Where,

$f_{c d 1}=0,85 \cdot \alpha_{v 2} \cdot f_{c d} ;$

$f_{c d 3}=0,72 \cdot \alpha_{v 2} \cdot f_{c d}$;

$\alpha_{\mathrm{v} 2}=1-\mathrm{f}_{\mathrm{ck}} / 250, \mathrm{f}_{\mathrm{ck}} \mathrm{k}$ em MPa;

$\mathrm{A}_{\mathrm{p}, \mathrm{sp}}=\frac{\pi\left(a_{\text {pile }}+2 d^{\prime}\right)}{4}$, for round pile, and $\mathrm{A}_{\mathrm{p}, \mathrm{sp}}=\left(\mathrm{a}_{\mathrm{pile}}+2 \mathrm{~d}^{\prime}\right)^{2}$, for square pile; $A_{c, s p}=\left(a_{c}+2 y\right)\left(b_{c}+2 y\right)$, for rectangular column.

Although there are similarities with the Fusco model, the STM proposed by Santos et al. [3] is not equivalent to the classical model replacing the area of the column for a spreading area. The spreading area is only a way to estimate the compression stresses in the struts. The proposal is based on the equivalence, in plane elements, of calculating the width of the diagonal strut by the geometry of the node or by the concept of spreading load, with a spreading angle equal to that of the diagonal strut, i. e. (Figure 10):

$a_{\text {strut }}=a_{c} / 2 \cdot \sin \theta+y \cdot \cos \theta$ or $a_{\text {strut }}=a_{c, s p} / 2 \cdot \sin \theta$

The design values of the compressive stress within the node below the column is adopted, in a conservative way, as the value established in item 22.1 of NBR 6118 [4] for CCC node, and it is independent of the number of piles. The nodes above the piles are considered as CCT.

Since the crushing strengths adopted do not consider any confinement by the triaxial compression or by plain concrete, comparisons with the test data were performed with two different limits for the node at the top: $0.85 \cdot \mathrm{f}_{\mathrm{cd}}$ and $\mathrm{f}_{\mathrm{cd} 1}$. The effectiveness factor $\alpha_{\mathrm{v} 2}$ was eliminated in one of the assessments.

The method consists in determining the depth of the CCC node below the column in an iterative manner, until the stress within the node (or in the concrete struts) is equal to the design value of the crushing strength. The calculation procedure is:

I. Define the initial depth of the top node (e. g., $y=0,2 d$ );

II. Determine $\theta$ (recommendation: $\theta \geq 45^{\circ}$ );
III. Determine the design compressive stress within the node

IV. If the design compressive stress within the node is different from the design value of the crushing strength, update $y$ until $\sigma_{c d, c}=f_{c d 1} ;$

$V$. Determine $\theta$ with the final value of $y$ and the main reinforcement;

VI. Check if the design stress within the node above the piles is limited to $f_{c d 3}$;

VII. Determine the secondary distributed reinforcement for cracking control.

The Santos et al. [3] strut-and-tie model, in comparison with the classical method [1], results in higher amounts of reinforcement. The only possible exception is for two-pile caps due to the factor of 1.15 proposed by Blévot and Frémy [1].

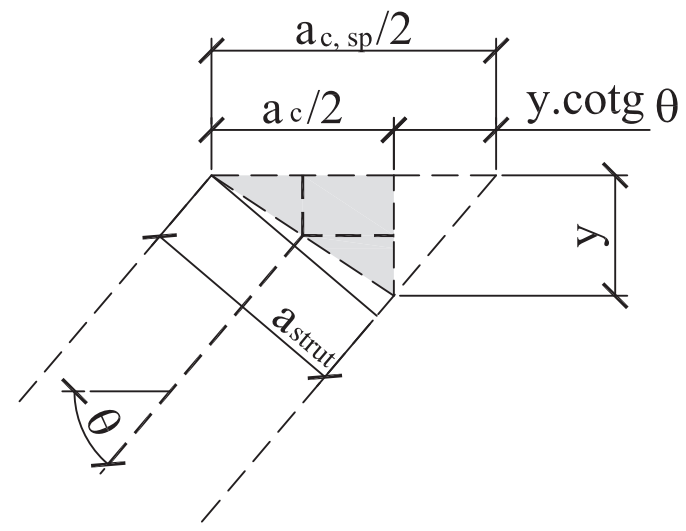

CCC node geometry

\section{Figure 10}

Equivalence between spreading of the load and node geometry proposed by Schlaich et al. [20] 


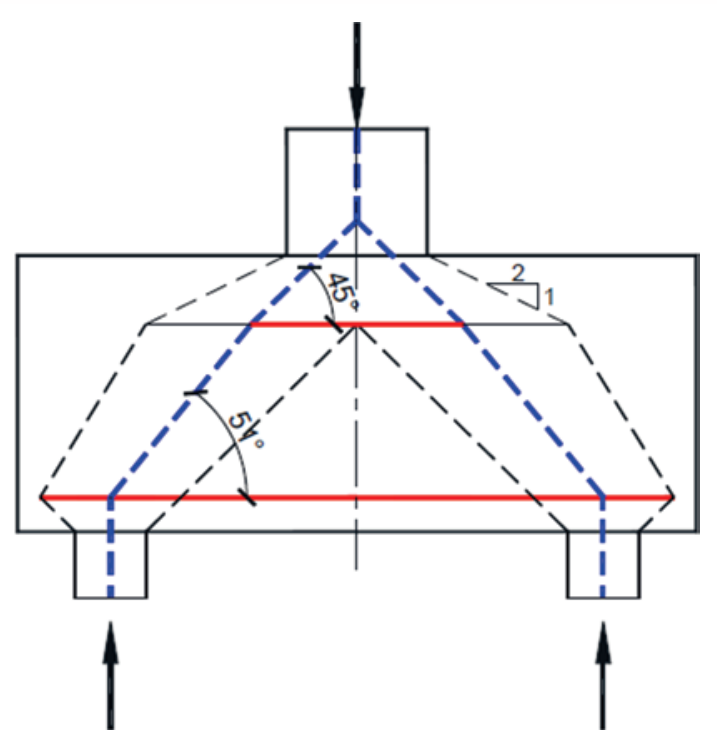

Figure 11

Possible stress field by the Fusco [5] model

\subsection{Some differences between models}

The Santos et al. [3] model assumes sufficient redistribution capacity of internal forces so that the Ultimate Limit State (ULS) is achieved only when the reinforcement and the node below the column reach their design strength limit.

This hypothesis is adequate only if the concrete strut and the node above the piles do not crush before the yielding of the reinforcement, since the redistribution capacity of internal forces depends on the plastic deformation of the steel.

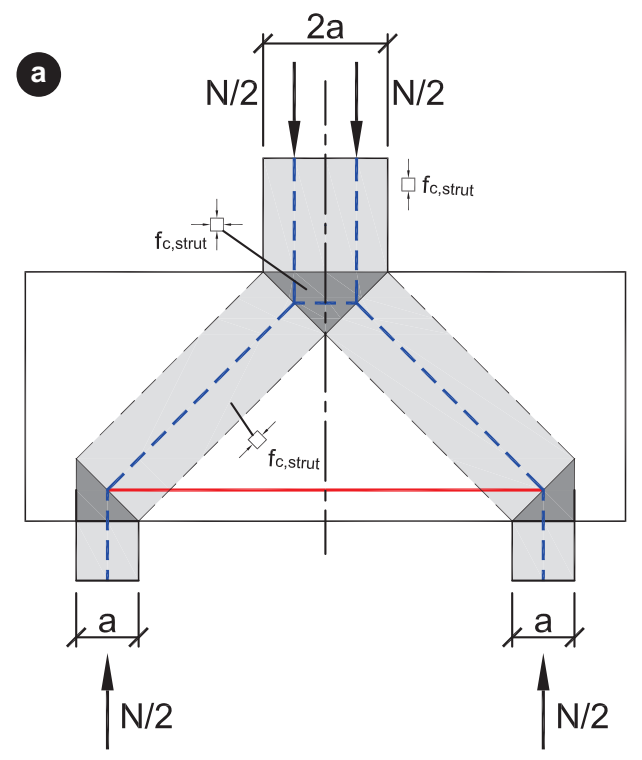

The Santos et al. [3] model has similarities with the bending theory and, equivalently, it is necessary to ensure sufficient capacity of plastic deformation. This can be done in a simplified way, as is common in the design of beams, by limiting the depth of the neutral axis (or depth of CCC node). Preliminary studies on test data of pile caps with brittle failure show that the ratio limit $y / d$ not greater than 0.3 is adequate.

In contrast, the Blévot and Frémy [1] model assumes that the angle of the diagonal strut is determined only by geometrical data, thus implying that three separate limit states exist: when the design value of stresses in the node below the column or in the node above the piles or in the reinforcement reached the design compressive/tension strength.

When designing the pile caps by the classical method, if the ultimate limit state is exceeded in one of the nodes (i.e. in the diagonal strut), only by changing the geometry of the pile cap (height, for example) or the strength of the concrete can the problem be solved. However, in the Santos et al. [3] model, for the same column force, these parameters may be the same by increasing the amount of reinforcement. In this case, the flexural strength of the pile cap grows with the increments of the tension forces in the reinforcement and of the compressive forces in the node below the column, despite the decreases in the lever arm.

The differences between the two models is very important, as increasing the strength of the concrete or the geometry of the pile cap can be costly.

The Fusco [5] model also assumes that the strength of the node at the base of the column depends on the quantity of reinforcement. However, since the angle of spreading the load is very large, the angle of inclination of the diagonal strut could be greater than the angle defined by the classical model, which produces unrealistic geometry of the strut-and-tie model allowing tensile stresses in the upper region of the pile caps (Figure 11).

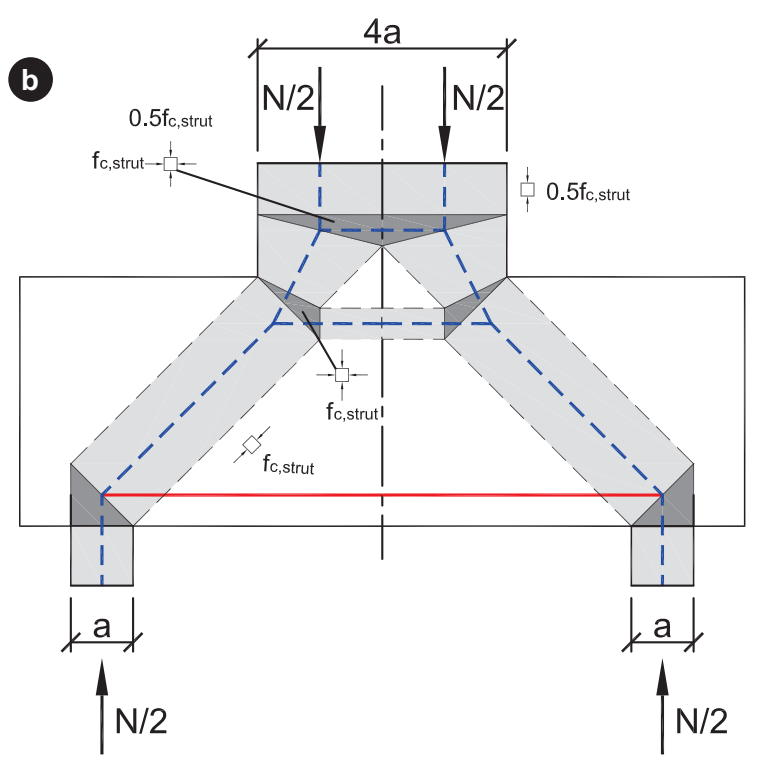

\section{Figure 12}

Strut-and-tie models for two-pile caps: a) The stress in the column is equal to the strength of concrete and $b$ ) The stress in the column is lower than the strength of concrete 
The Fusco model was idealized for angles of the diagonal struts of $33.7^{\circ}(\operatorname{arctg} 2 / 3)$. In order to eliminate the problem illustrated in Figure 11, the spreading load could be smaller for larger angles; however, comparisons with the tests was performed with the original prescriptions.

\section{Comparative study}

Table 3 presents the ratio of measured pile cap capacity to predicted capacity for the models mentioned above (except for the Zhou and Adebar [8] model). The Santos et al. [3] model is shown twice because one of them did not use the effectiveness factor in the crushing strength of the concrete strut.

It interesting to note that the classical model [1] and the Santos et al. [3] model have similar predictions, and that the Fusco model was conservative due to the simplified verification above the piles. Moreover, in some of the pile caps tested, it was not possible to determine $x$ (depth of load spreading).

Table 4 summarizes the predicted failure mode. In the "Blévot model" there are three possible failure modes, which are: yielding of reinforcement (Reinf. In Table 4), crushing of the node below the column (Column) or crushing of the node above the piles (pile). In the model proposed by Santos et al. [3] (and Fusco [5] model), generally, there are only two failure modes: (Reinf./Column) crushing of the upper node after the yielding of the reinforcement or crushing of lower node without reinforcement yielding (pile).

In addition, it is noticed that the coefficients of variation (cv) are high, showing the complexity of the problem. Park et al. [18] and

\section{Table 3}

Comparisons between Blévot, Fusco e Santos et al. predictions and experimentally observed failure loads

\begin{tabular}{|c|c|c|c|c|c|}
\hline \multirow{2}{*}{ Pile cap } & \multirow{2}{*}{$\begin{array}{l}F_{\text {test }} \\
\text { (tf) }\end{array}$} & \multirow{2}{*}{ Blévot } & \multicolumn{3}{|c|}{$F_{\text {fest }} / \mathbf{F}_{\text {predicted }}$} \\
\hline & & & Santos et al. ${ }^{1}$ & Santos et al. ${ }^{2}$ & Fusco \\
\hline $4 \mathrm{~N} 2$ & 658 & 1.10 & 1.16 & 1.14 & 1.04 \\
\hline $4 \mathrm{~N} 2^{\mathrm{bis}}$ & 739 & 1.12 & 1.20 & 1.18 & 1.03 \\
\hline $4 \mathrm{~N} 4$ & 753 & 1.01 & 1.04 & 1.03 & 1.85 \\
\hline $4 N 4^{\text {bis }}$ & 875 & 1.06 & 1.09 & 1.07 & 1.79 \\
\hline 2,2 & 81 & 1.11 & 1.18 & 1.16 & 1.34 \\
\hline 2,3 & 74 & 1.20 & 1.26 & 1.24 & 1.27 \\
\hline 3,1 & 47.5 & 1.20 & 1.30 & 1.27 & 1.19 \\
\hline $1 \mathrm{~A}, 2^{\mathrm{bis}}$ & 117.75 & 1.16 & 1.23 & 1.21 & 1.92 \\
\hline $1 \mathrm{~A}, 3$ & 118.5 & 1.16 & 1.27 & 1.24 & 1.76 \\
\hline $9, A 1$ & 120 & 1.21 & 1.14 & 1.13 & - \\
\hline $9, \mathrm{~A} 2$ & 190 & 1.28 & 1.27 & 1.26 & - \\
\hline $10,1 a$ & 85 & 1.15 & 1.26 & 1.23 & 1.61 \\
\hline $10,1 b$ & 80 & 0.89 & 1.01 & 0.98 & 1.21 \\
\hline $11,1 a$ & 56.25 & 0.82 & 0.83 & 0.82 & 1.37 \\
\hline $11,1 b$ & 49.25 & 0.99 & 0.97 & 0.97 & - \\
\hline $11,2 a$ & 55.75 & 0.68 & 0.69 & 0.68 & 1.18 \\
\hline $11,2 b$ & 58.5 & 0.76 & 0.77 & 0.76 & 1.27 \\
\hline $\mathrm{A} 2$ & 142 & 1.11 & 1.16 & 1.15 & 1.77 \\
\hline A3 & 134 & 1.03 & 1.10 & 1.08 & 1.49 \\
\hline A5 & 140 & 1.12 & 1.15 & 1.13 & 1.78 \\
\hline A6 & 123 & 1.01 & 1.02 & 1.01 & 1.61 \\
\hline A8 & 151 & 1.18 & 1.24 & 1.22 & 1.88 \\
\hline BPC-20-1 & 51.9 & 1.43 & 1.43 & 1.43 & 1.43 \\
\hline BPC-20-2 & 52.9 & 1.46 & 1.46 & 1.46 & 1.46 \\
\hline BPC-25-1 & 81.8 & 1.35 & 1.39 & 1.36 & 1.35 \\
\hline BPC-25-2 & 81.3 & 1.35 & 1.35 & 1.35 & 1.34 \\
\hline BPC-20-30-1 & 50 & 1.68 & 1.68 & 1.68 & 1.68 \\
\hline BPC-20-30-2 & 49.5 & 1.67 & 1.67 & 1.67 & 1.67 \\
\hline BPC-30-30-1 & 103.9 & 1.57 & 1.57 & 1.57 & 1.57 \\
\hline BPC-30-30-2 & 102.9 & 1.56 & 1.56 & 1.56 & 1.56 \\
\hline BP-30-25-1 & 85.3 & 1.38 & 1.38 & 1.38 & 1.36 \\
\hline BPC-30-25-2 & 87.2 & 1.42 & 1.42 & 1.42 & 1.39 \\
\hline \multicolumn{2}{|c|}{ Mean } & 1.19 & 1.23 & 1.21 & 1.49 \\
\hline \multicolumn{2}{|c|}{ Standard deviation } & 0.25 & 0.24 & 0.24 & 0.25 \\
\hline \multicolumn{2}{|c|}{ Coefficient of variation } & 0.21 & 0.19 & 0.20 & 0.17 \\
\hline
\end{tabular}

Coefficient of variation

Notes: Rapid assay, without considering the (long term) 0.85 factor; Partial factors ( $\gamma_{c}$ and $\gamma_{s}$ ) were eliminated (or assumed equal to the unit)

Design strength of the CCC node prescribed by NBR 6118 [4]; ${ }^{2}$ Design strength of the CCC node without the effectiveness factor $\alpha_{\mathrm{v} 2}$. 


\section{Table 4}

Failure modes predicted by Blévot, Fusco e Santos et al. models

\begin{tabular}{|c|c|c|c|c|}
\hline Pile cap & Blévot & Santos et al. ${ }^{1}$ & Santos et al. ${ }^{2}$ & Fusco \\
\hline $4 \mathrm{~N} 2$ & Reinf. & Reinf./Column & Reinf./Column & Reinf./Column \\
\hline $4 \mathrm{~N} 2^{\mathrm{bis}}$ & Reinf. & Reinf./Column & Reinf./Column & Reinf./Column \\
\hline $4 \mathrm{~N} 4$ & Reinf. & Reinf./Column & Reinf./Column & Pile \\
\hline $4 \mathrm{~N} 4^{\text {bis }}$ & Reinf. & Reinf./Column & Reinf./Column & Pile \\
\hline 2,2 & Reinf. & Reinf./Column & Reinf./Column & Pile \\
\hline 2,3 & Reinf. & Reinf./Column & Reinf./Column & Pile \\
\hline 3,1 & Reinf. & Reinf./Column & Reinf./Column & Pile \\
\hline $1 \mathrm{~A}, 2^{\mathrm{bis}}$ & Column & Pile & Pile & Pile \\
\hline $1 \mathrm{~A}, 3$ & Reinf. & Reinf./Column & Reinf./Column & Pile \\
\hline $9, \mathrm{Al}$ & Column & Pile & Pile & - \\
\hline $9, \mathrm{~A} 2$ & Column & Pile & Pile & - \\
\hline $10,1 a$ & Column & Pile & Pile & Pile \\
\hline $10,1 b$ & Column & Pile & Pile & Pile \\
\hline $11,1 a$ & Column & Pile & Pile & Pile \\
\hline $11,1 b$ & Column & Pile & Pile & - \\
\hline $11,2 a$ & Column & Pile & Pile & Pile \\
\hline $11,2 \mathrm{~b}$ & Column & Pile & Pile & Pile \\
\hline $\mathrm{A} 2$ & Column & Reinf./Column & Reinf./Column & Pile \\
\hline A3 & Reinf. & Reinf./Column & Reinf./Column & Pile \\
\hline A5 & Column & Reinf./Column & Reinf./Column & Pile \\
\hline A6 & Column & Reinf./Column & Reinf./Column & Pile \\
\hline A8 & Column & Reinf./Column & Reinf./Column & Pile \\
\hline BPC-20-1 & Reinf. & Reinf. & Reinf. & Reinf. \\
\hline BPC-20-2 & Reinf. & Reinf. & Reinf. & Reinf. \\
\hline BPC-25-1 & Reinf. & Reinf./Column & Reinf./Column & Reinf./Column \\
\hline BPC-25-2 & Reinf. & Reinf. & Reinf. & Reinf./Column \\
\hline BPC-20-30-1 & Reinf. & Reinf. & Reinf. & Reinf. \\
\hline BPC-20-30-2 & Reinf. & Reinf. & Reinf. & Reinf. \\
\hline BPC-30-30-1 & Reinf. & Reinf. & Reinf. & Reinf./Column \\
\hline BPC-30-30-2 & Reinf. & Reinf. & Reinf. & Reinf./Column \\
\hline BP-30-25-1 & Reinf. & Reinf. & Reinf. & Reinf./Column \\
\hline BPC-30-25-2 & Reinf. & Reinf. & Reinf. & Reinf./Column \\
\hline
\end{tabular}

${ }^{1}$ Design strength of the CCC node prescribed by NBR 6118 [4]; ${ }^{2}$ Design strength of the CCC node without the effectiveness factor $\alpha_{\mathrm{v} 2}$.

Table 5

Statistical parameters for model uncertainty $\left(F_{\text {ensaio }} / F_{\text {teórico }}\right)$ separated by researcher

\begin{tabular}{|c|c|c|c|c|c|}
\hline \multirow{2}{*}{ Researcher } & \multirow{2}{*}{$\begin{array}{c}\text { Statistical } \\
\text { parameters }\end{array}$} & \multicolumn{4}{|c|}{$F_{\text {test }} / F_{\text {predicted }}$} \\
\hline & & Blévot & Santos et al. ${ }^{1}$ & Santos et al. ${ }^{2}$ & Fusco \\
\hline \multirow{3}{*}{$\begin{array}{c}\text { Blévot and Frémy } \\
{[1]}\end{array}$} & Mean & 1.05 & 1.10 & 1.08 & 1.42 \\
\hline & Standard deviation & 0.17 & 0.19 & 0.18 & 0.31 \\
\hline & $\mathrm{CV}$ & 0.16 & 0.17 & 0.17 & 0.22 \\
\hline \multirow{3}{*}{$\begin{array}{l}\text { Clarke } \\
\text { [9] }\end{array}$} & Mean & 1.09 & 1.13 & 1.12 & 1.71 \\
\hline & Standard deviation & 0.07 & 0.08 & 0.08 & 0.15 \\
\hline & $\mathrm{cV}$ & 0.06 & 0.07 & 0.07 & 0.09 \\
\hline \multirow{3}{*}{$\begin{array}{c}\text { Susuki et al. } \\
{[10]}\end{array}$} & Mean & 1.49 & 1.49 & 1.49 & 1.48 \\
\hline & Standard deviation & 0.12 & 0.12 & 0.12 & 0.13 \\
\hline & $\mathrm{cV}$ & 0.08 & 0.08 & 0.08 & 0.09 \\
\hline
\end{tabular}

${ }^{1}$ Design strength of the CCC node prescribed by NBR 6118 [4]; ${ }^{2}$ Design strength of the CCC node without the effectiveness factor $\alpha_{\mathrm{v} 2}$. 
Adebar and Zhou [8] compared some experiments with the theoretical results of strut-and-tie models and the bending theory (slab analogy), and even with relatively high cv, the STM showed more reliable predictions.

In Table 5, the statistical parameters are calculated assuming separate groups of tests by researcher. This analysis shows significant differences in the prediction of the failure load when only the assays of Susuki et al. [10] is selected. For the test data of Blévot and Frémy [1] and Clarke [9], again the predictions load by [1] and [3] are similar, the Fusco model remains conservative.

Within the selected tests of [1], there are 4 specimens $(11,1 \mathrm{a}$, $11,1 b, 11,2 a$ and $11,2 b)$ in that the predictions by STM were very unsafe. Blévot and Frémy ([1]) describe that the failures of these pile caps occurred with large vertical and inclined cracking, typical of brittle failure. This behavior may indicate a slipping of the reinforcement due to insufficient anchorage length. The mean value and the coefficient of variation of the ratio between experimental load and theoretical load, without these tests, are equal to: 1.14 and 0.09 , for [1] model; 1.20 and 0.08 , for [3] (without the effectiveness factor). The improvement in the prediction of both models was expected (due to a reduction in the standard deviation).

The assays performed by Susuki et al. [10] had large columns resulting in failure by bending with relatively low vertical stresses within the column (even for failure load) compared to the compressive concrete strength. Table 5 allows observing that the Santos et al. method [3] becomes equivalent to the classical method, since even with $y$ equal to zero, the crushing strength of the diagonal strut is higher than the internal force in the concrete.

The conservatism observed from Suzuki's tests suggests that the strut-and-tie model to be used differs from the discussed models, i.e., this case is outside the method applicability, although they can

\section{Table 6}

Comparisons between the Fusco model and experimental results of Blévot \& Frémy [1]

\begin{tabular}{ccc}
\hline \multirow{2}{*}{ Pile cap } & \multicolumn{2}{c}{$\mathbf{F}_{\text {test }} / \mathbf{F}_{\text {predicted }}$} \\
\cline { 2 - 3 } & Fusco $^{1}$ & Fusco $^{2}$ \\
\hline $4 \mathrm{~N} 2$ & 1.04 & 1.04 \\
$4 \mathrm{~N} 2^{\text {bis }}$ & 1.03 & 1.03 \\
$4 \mathrm{~N} 4$ & 1.85 & 0.85 \\
$4 \mathrm{~N} 4^{\text {bis }}$ & 1.79 & 0.91 \\
2,2 & 1.34 & 0.99 \\
2,3 & 1.27 & 1.09 \\
3,1 & 1.19 & 1.19 \\
$1 \mathrm{~A}, 2^{\text {bis }}$ & 1.92 & 0.78 \\
$1 \mathrm{~A}, 3$ & 1.76 & 0.99 \\
$10,1 \mathrm{a}$ & 1.61 & 0.69 \\
$10,1 \mathrm{~b}$ & 1.21 & 0.68 \\
$11,1 \mathrm{a}$ & 1.37 & 0.48 \\
$11,2 \mathrm{a}$ & 1.18 & 0.47 \\
$11,2 \mathrm{~b}$ & 1.27 & 0.53 \\
Média & 1.45 & 0.79 \\
Desvio & 0.28 & 0.23 \\
cv & 0.20 & 0.29 \\
\hline
\end{tabular}

${ }^{1}$ Limiting the vertical stresses above the piles:

${ }^{2}$ Limiting the stress in the diagonal strut at the top of the piles. be used in a conservative way. A more suitable strut-and-tie model is illustrated in Figure 11.

Since the Fusco model was overly conservative, given the limitation of the vertical stresses in the spreading area of the piles, a more refined analysis was performed in which the stresses within the diagonal strut above the piles was limited in $f_{c d}$. The summary of the two analyses is shown in Table 6.

The model proposed by Fusco [5] was very sensitive to the spreading pile area used, for example, in the scale reduced tests performed by [1] (Figure 2). It was considered that it is not possible to spread the load, considering that the distance from the edge of the pile to the edge of the pile cap is $2 \mathrm{~cm}$ of unreinforced concrete. If this $2 \mathrm{~cm}$ are considered in the spreading area, the bearing capacity of the pile cap increases $65 \%$, which significantly improves the prediction regarding this group of tests.

\section{Conclusions}

In this study, four strut-and-tie models applied to pile caps were analyzed, and three of them were compared with experimental results. The classical method (Blévot and Frémy [1]), which is widely used in Brazil, showed adequate predictions, albeit sometimes conservative. This model determines the stresses in the concrete diagonal strut in a conventional form, resulting in very high stresses in relation to the strength of concrete.

The Fusco model [5] is based on the classical model and introduces the concept of spreading the load, in order to more realistically determine the compressive stresses in the diagonal strut. Comparisons with assays show that the model is very sensitive to the spreading area. Additionally, Fusco [5] idealized the model for angles of inclination about $33.7^{\circ}$; since the majority of the tests had higher inclinations, the predictions of this model were very conservative.

The model recently presented by Santos et al. [3] mixed the Blévot and Frémy [1] model with the Fusco [5] spreading load concept. This is consistent with the theoretical concepts of strut-and-tie models and stress fields. Experimental comparisons show that the predictions of this model are similar to the classical method, i.e., it is also adequate for designing pile caps.

The safety level of the model recently proposed by Santos et al. [3] is equivalent to the safety level of the Blévot and Frémy [5] model, widely and successfully used in Brazil. However, the great difference between the two methods could not be evidenced by the available tests, since the mechanical ratio of reinforcement in the specimens was not high. The Santos et al. [3] model can be used with the design strength of concrete struts and the design values of the compressive stress within nodes by the Brazilian standard (calibrated for plane elements) without excessive conservatism in comparison with the Blévot and Frémy [5] model.

Comparisons with experimental results indicate that the elimination of the effectiveness coefficient is feasible, which is proposed as an improvement to the Santos el al. [3] model.

\section{References}

[1] BLEVOT, J.; FRÉMY, R. (1967). Semelles sur pieux. Analles de l'Institut Technique du Batiment et des Travaux Publics., Paris, v.20, n.230. 
[2] COMITÉ EURO-ITERNATIONAL DU BÉTON (1970). CEB-FIP Recommandations particulières au calcul et à l'execution des semelles de fondation. Bulletin d'Information, Paris, n.73.

[3] Santos, D. M.; Marquesi, M. L.; Stucchi, F. R. (2015). Dimensionamento de blocos de fundações sobre 2 e 4 estacas. In: ABNT NBR 6118:2014 comentários e exemplos de aplicação. IBRACON, 455-478, São Paulo.

[4] ASSOCIAÇÃO BRASILEIRA DE NORMAS TÉCNICAS (2014). NBR6118 - Projeto de estruturas de concreto - Procedimento. Rio de Janeiro.

[5] FUSCO, P. B. (1995). Técnicas de armar as estruturas de concreto. Editora PINI, São Paulo.

[6] ADEBAR, P.; KUCHMA, D. COLLINS, M. P. (1990). Strutand-tie models for design of pile caps: An experimental study. ACl Journal, v. 87, n.1, p.81-91.

[7] ADEBAR, P.; ZHOU, Z. (1993). Bearing strength of compressive struts confined by plain concrete. ACI Journal, v. 90 , n.5, p.534-541.

[8] ADEBAR, P.; ZHOU, Z. (1996). Design of deep pile caps by strut-and-tie models. ACI Journal, v. 93, n.4, p.1-12.

[9] CLARKE, J. L. (1973). Behavior and design of pile caps with four piles. Cement and concrete association, London, 19p. (Technical Report, n. 42.489).

[10] SUZUKI, K.; OTSUKI, K.; TSUBATA, T. (1998). Influence of bar arrangement on ultimate strength of four pile caps. Transactions of the Japan Concrete Institute, V. 20, pp. 195-202.

[11] SUZUKI, K.; OTSUKI, K.; TSUBATA, T. (1999). Experimental Study on Four-Pile Caps with Taper. Transactions of the Japan Concrete Institute, V. 21, pp. 327-334.

[12] SUZUKI, K.; OTSUKI, K.; TSUHIYA, T. (2000). Influence of Edge Distance on Failure Mechanism of Pile Caps. Transactions of the Japan Concrete Institute, V. 22, pp. 361-36.

[13] SUZUKI, K., and OTSUKI, K., (2002). Experimental Study on Corner Shear Failure of Pile Caps, Transactions of the Japan Concrete Institute, V. 23, 2002

[14] CAO, J. (2009). The shear behavior of the reinforced concrete four-pile caps. University of Southampton, United Kingdom, PhD Thesis.

[15] MIGUEL, G. M. (2000). Análise experimental e numérica de blocos sobre três estacas. Tese (doutorado) - Escola de Engenharia de São Carlos, Universidade de São Paulo, São Carlos, SP.

[16] BARROS, R. (2013). Análise numérica experimental de blocos de concreto armado sobre duas estacas com cálice externo, parcialmente embutido e embutido utilizado na ligação pilar-fundação. Tese (doutorado) - Escola de Engenharia de São Carlos, Universidade de São Paulo, São Carlos, SP.

[17] MUNHOZ, F. S. (2014). Análise experimental e numérica de blocos rígidos sobre duas estacas com pilares de seções quadradas e retangulares e diferentes taxas de armadura. Tese (doutorado) - Escola de Engenharia de São Carlos, Universidade de São Paulo, São Carlos, SP.

[18] PARK, J., KUCHMA, D. e SOUZA, R. (2008). Strength predictions of pile caps by a strut-and-tie model approach. Canadian Journal of Civil Engineering, v. 31, n.1, p.109-119.

[19] ACI COMMITTEE 318 (2014). Building Code Requirements for Structural Concrete: (ACl 318-14) and Commentary. Farmington Hills, Ml: American Concrete Institute.

[20] SCHLAICH, J.; SCHÄFER, K.; JENNEWEIN, M. (1987). Toward a consistent design of structural concrete. PCI Journal, v.32, n.3; p.75-150.

[21] MUTTONI, A.; SCHWARTZ, J.; THÜRLIMANN B. (1997). Design of concrete structures with stress fields. Birkhäuser, 143p.

[22] CARVALHO, M. L. (2018). Análise de confiabilidade de modelos de capacidade resistente de blocos de fundação. Dissertação (mestrado) - Escola Politécnica da Universidade de São Paulo, São Paulo, SP. 